\title{
Code Mixing and Code Switching in Twivortiare 2 Novel By Ika Natassa
}

\author{
Rizky Mirani Desi Pratama ${ }^{1}$, Dwi Puji Hastuti ${ }^{2}$ \\ ${ }^{12}$ Universitas Bina Sarana Informatika \\ email: ${ }^{1}$ rizky.rrr@bsi.ac.id; ${ }^{2}$ dwi.dsu@bsi.ac.id

\begin{tabular}{ccc}
\hline Diterima & Direvisi & Disetujui \\
$10-08-2020$ & $31-08-2020$ & $20-09-20$ \\
\hline
\end{tabular}

\begin{abstract}
The research aims to find the classification types of code switching and code mixing in Twivortiare 2 novel then describe the influencing using types of code switching and code mixing. Twovortiare 2 novel has many sentences used code mixing and code switching as the utterance which has intention clearly. Descriptive qualitative method are used as the methodology in this research which means based on the data that gained through reading the novel thus classify types of code switching and code mixing every sentences clearly through the dialogue of the novel then find the influence of the utterance using code switching and code mixing. The research focused on the types of code switching (inter-sentential, intra-sentential, and tag-switching) and types of code mixing (insertion, alternation, and Congruent Lexicalization) while combine with influencing os using code switching and code mixing. The results of the research are most of utterance using code mixing insertation and code switching - intra-setential in Twovortiare 2 novel.
\end{abstract}

Keywords: code mixing, code switching, twivortiare novel

Abstrak - Penelitian ini bertujuan untuk menemukan jenis klasifikasi pengalihan kode dan pencampuran kode dalam novel twivortiare 2 kemudian menggambarkan pengaruh penggunaan jenis pengalihan kode dan pencampuran kode dalam novel. Novel Twivortiare 2 memiliki banyak kalimat yang menggunakan pencampuran kode dan pengalilhan kode sebagai ucapan yang memiliki niat yang jelas. Metode kualitatif deskriptif digunakan sebagai metodologi dalam penelitian ini yang berarti berdasarkan data yang diperoleh melalui membaca novel sehingga dapat mengklasifikasikan jenis pengalihan kode dan pencampuran kode pada setiap kalimat dengan jelas melalui dialog novel. Penelitian ini berfokus pada jenis pengalihan kode (inter-sentential, intra-sentential, dan tag-switching) dan jenis pencampuran kode (insertion, alternation, and Congruent Lexicalization) dengan menggabungkan penggunaan dalam analisa. Hasil penelitian ditemukan bahwa banyak ucapan yang sebagian besar ucapan menggunakan pencampuran kode - penyisipan dan pencampuran kode - intra-setential.

Kata kunci: pencampuran kode, pengalihan kode, novel twivortiare

\section{INTRODUCTION}

Language is the most important component in human life. Language is a communication tool used by human to communicate with each other. Human uses language to express their idea and feeling. There are so many languages in this world. This gave rise to the human new habit of speaking in more than one language in a process of communication. This phenomenon usually called code mixing and code switching.

Code is a language or a variety of language. The variety of language in Indonesia includes code mixing and code switching. The phenomenon can be found in many things, for example, in newspaper, film, novel, song, etc (Husna, 2010). Code switching refers to the process of switching from one language to another language. As Thelander in (Chaer \& Agustina, 2010) state that code-switching is the use of two language or more) by a speaker in the same communication event. The use of code switching also shows that people have proficiency of some language. Code-switching refers to the capacity of using, replacing, or switching two language in use (Bullock \& Toribio, 2009). Code switching into three categories. There are tag switching codeswitching, inter-sentential code switching, intrasentential code switching (Romaine, 1995).

Tag switching is sometimes called emblematic switching where the switch is simply an interjection, sentence filler in the other language that serves as an ethnic identity marker (Holmes \& Wilson, 2017). Inter-sentential code switching is the alternation in a single discourse between two languages, where the switching occurs after a sentence in the first language has been completed and the next sentence starts with a new language or on the other hand, means that intersentential code-switching occurs between different number of sentences (Appel \& Muysken, 2006). Intra-sentential code-switching 
refers to the switch from one language to another in a sentence that involves the syntactic units of words, phrases, or clauses (Poplack, 1980).

Code mixing occurs when a conversation use both languages together to the extent that they change from one language to the other in the course of a single utterance (Wardhaugh, 1998). Code mixing is the use of two languages or more by inserting one language elements into another language element in one utterance (Suwito, 1985).(Muysken, 2000) divided code mixing into three types:

\section{Insertion}

Approaches that depart from the notion of insertion view the constraints in terms of structural properties of some base or matrix structure. Here the process of code-mixing is conceived as something akin to borrowing: the insertion of an alien lexical or phrasal category into a given structure. The difference would simply be the size and type of element inserted, e.g. noun versus noun phrase. For example, "Twitter udah jadi platform berita yang mungkin paling real-time."

\section{Alternation}

Approaches departing from alternation view the constraints on mixing in terms of the compatibility or equivalence of the languages involved at the switch point. In this perspective code-mixing is akin to the switching of codes between turns or utterances. For example : "Dan entah bagaimana, it makes us feel okay."

\section{Congruent Lexicalization}

The notion of congruent lexicalization underlies the study of style shifting and dialect or standard variation rather than bilingual language use proper. For example : Diagonis dokter bikin dia putus asa.

The use of code switching and code mixing is very common in multilingual society. Nowadays, the novel writer began using code switching and code mixing to indicate that code switching and code mixing have already become common phenomenon. This phenomenon is one of the effects of information technology development. People all over the world can communicate each other by utilizing information technology, this condition makes people accustomed to use more than one language in their daily life even in creating a literary work like a novel. For example is Twivortiare 2 novel by Ika Natassa, there are many code switching and code mixing cases that found in this novel. Based on that reason, the paper examine the use of code switching and code mixing in the Twivortiare 2 novel by Ika Natassa.

\section{RESEARCH METHODOLOGY}

The research uses descriptive qualitative method by collected the data then analysis the data. The data is taken form novel Twivortiare 2 by Ika Natassa. Qualitative research is more holistic and often involves a rich collection of data from various sources to gain a deeper understanding of individual participants, including their opinion, perspectives and attitudes (Nassaji, 2015). By using this method, the research will elaborate and answer the problem by using dialogues and read thoroughly to get the understanding of the content as a whole. The research scrutinizes types of code-mixing and codeswitching that are used in the novel.

\section{FINDING AND RESULTS}

This research finds many code-mixing and codeswitching cases in Twivortiare 2 novel. Then, this research categorized the types of code-mixing and code-switching that found in novel by adjusting the theory from Pieter Muysken and Shana Poplack

Here are the list of code-mixing and code-switching cases in Twivortiare 2 novel :

Table 1. List of Code-Mixing and Code-Switching

\begin{tabular}{|c|c|c|c|}
\hline No & Utterances & Code Mixing & $\begin{array}{l}\text { Code } \\
\text { Switching }\end{array}$ \\
\hline 1 & $\begin{array}{l}\text { In the } \\
\text { backseat with } \\
\text { si anti public } \\
\text { display of } \\
\text { affection yang } \\
\text { ikut nganter } \\
\text { ke bandara. } \\
\text { Karena ada } \\
\text { sopir, si anti } \\
\text { public } \\
\text { display of } \\
\text { affection tidur } \\
\text { di sebelah gue } \\
\text { sambil } \\
\text { megang } \\
\text { tangan aja. } \\
\text { Cute. - p. } \\
255 .\end{array}$ & Insertion & $\begin{array}{l}\text { Intra- } \\
\text { sentential }\end{array}$ \\
\hline 2 & $\begin{array}{l}\text { Waktu gue } \\
\text { lunch dengan } \\
\text { ibu mertua } \\
\text { minggu lalu, } \\
\text { salah satu } \\
\text { tante si Beno } \\
\text { itu nelepon } \\
\text { ibu, dan ibu }\end{array}$ & $\begin{array}{l}\text { Insertion } \\
\text { Congruent } \\
\text { Lexicalization }\end{array}$ & $\begin{array}{l}\text { Intra- } \\
\text { sentential }\end{array}$ \\
\hline
\end{tabular}




\begin{tabular}{|c|c|c|c|}
\hline & $\begin{array}{l}\text { cerita tentang } \\
\text { kehamilan } \\
\text { gue. }- \text { p. } 290 .\end{array}$ & & \\
\hline 3 & $\begin{array}{l}\text { Tiap main ke } \\
\text { apartmen gue, } \\
\text { juga langsung } \\
\text { menjarah } \\
\text { kulkas. } \\
\text { Makanya } \\
\text { selama } \\
\text { pacaran } \\
\text { grocery } \\
\text { shopping gue } \\
\text { tambah. That } \\
\text { dude sure } \\
\text { loves food. } \\
\text { Untung nggak } \\
\text { jadi gendut. - } \\
\text { p. } 300 .\end{array}$ & Insertion & $\begin{array}{l}\text { Intra- } \\
\text { sentential }\end{array}$ \\
\hline 4 & $\begin{array}{l}\text { Tiap main ke } \\
\text { apartmen gue, } \\
\text { juga langsung } \\
\text { menjarah } \\
\text { kulkas. } \\
\text { Makanya } \\
\text { selama } \\
\text { pacaran } \\
\text { grocery } \\
\text { shopping gue } \\
\text { tambah. That } \\
\text { dude sure } \\
\text { loves food. } \\
\text { Untung nggak } \\
\text { jadi gendut. - } \\
\text { p. } 300 .\end{array}$ & alternation & $\begin{array}{c}\text { Inter- } \\
\text { sentential }\end{array}$ \\
\hline 5 & $\begin{array}{l}\text { Kami berdua } \\
\text { senang } \\
\text { banget, } \\
\text { banget! Tapi } \\
\text { ada a part of } \\
\text { us juga yang } \\
\text { takut. Takut } \\
\text { ga bisa jadi } \\
\text { orangtua dan } \\
\text { contoh yang } \\
\text { baik untuk } \\
\text { anak ini. - p. } \\
319 .\end{array}$ & Insertion & $\begin{array}{c}\text { Intra- } \\
\text { sentential }\end{array}$ \\
\hline 6 & $\begin{array}{l}\text { Mau berburu } \\
\text { new bed yang } \\
\text { gede banget } \\
\text { biar muat } \\
\text { bobo bertiga } \\
\text { sama Lil Ndut. } \\
\text { - p. } 338 .\end{array}$ & Insertion & $\begin{array}{c}\text { Intra- } \\
\text { sentential }\end{array}$ \\
\hline 7 & $\begin{array}{lr}\text { Bad } & \text { habit } \\
\text { yang } & \text { itu } \\
\text { belum hilang } \\
\text { sih, dan gue } \\
\text { masih tetap }\end{array}$ & Insertion & $\begin{array}{c}\text { Intra- } \\
\text { sentential }\end{array}$ \\
\hline
\end{tabular}

\begin{tabular}{|c|c|c|c|}
\hline & $\begin{array}{l}\text { jadi }{ }^{2} \text { tukang } \\
\text { pungut. } \\
\text { p.359 }\end{array}$ & & \\
\hline 8 & $\begin{array}{l}\text { Men are not } \\
\text { mind readers. } \\
\text { Semuanya } \\
\text { harus } \\
\text { dinyatakan } \\
\text { verbal, } \\
\text { hinting is } \\
\text { usually } \\
\text { useless. - p. } \\
383 \text {. }\end{array}$ & Alternation & $\begin{array}{c}\text { Intra- } \\
\text { sentential }\end{array}$ \\
\hline 9 & $\begin{array}{l}\text { Men are not } \\
\text { mind } \\
\text { readers. } \\
\text { Semuanya } \\
\text { harus } \\
\text { dinyatakan } \\
\text { verbal, hinting } \\
\text { is usually } \\
\text { useless. - p. } \\
383 \text {. }\end{array}$ & Alternation & $\begin{array}{c}\text { Inter- } \\
\text { sentential }\end{array}$ \\
\hline 10 & $\begin{array}{l}\text { Lil Ndut, nanti } \\
\text { tiap malam } \\
\text { Mommy yang } \\
\text { cerita-cerita } \\
\text { nggak apa- } \\
\text { apa ya, Nak. } \\
\text { Time for you } \\
\text { to listen to } \\
\text { other stories. } \\
\text { - p. } 387 \text {. }\end{array}$ & Alternation & $\begin{array}{c}\text { Inter- } \\
\text { sentential }\end{array}$ \\
\hline 11 & $\begin{array}{l}\text { Lebih } \\
\text { tepatnya } \\
\text { bukan ke } \\
\text { orangnya. But } \\
\text { bored of the } \\
\text { way we } \\
\text { interact, } \\
\text { sometimes. } \\
\text { Hidup gue } \\
\text { sama Beno } \\
\text { kan kayak } \\
\text { clock-work, } \\
\text { no surprise. - } \\
\text { p. } 409 \text {. }\end{array}$ & Insertion & $\begin{array}{c}\text { Intra- } \\
\text { sentential }\end{array}$ \\
\hline 12 & 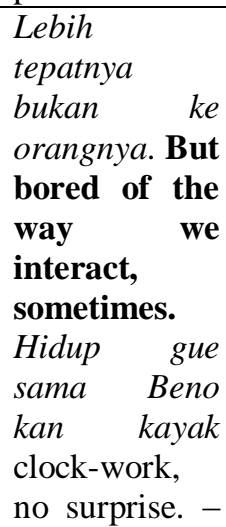 & Alternation & $\begin{array}{c}\text { Inter- } \\
\text { sentential }\end{array}$ \\
\hline
\end{tabular}




\begin{tabular}{|c|c|c|c|}
\hline & p. 409 & & \\
\hline 13 & $\begin{array}{lr}\text { Karena } & \text { Wina } \\
\text { naksir, we } & \text { we } \\
\text { ended } & \text { up } \\
\text { hanging out } \\
\text { with Diego a } \\
\text { lot. }- \text { p. } 412\end{array}$ & Alternation & $\begin{array}{c}\text { Intra- } \\
\text { sentential }\end{array}$ \\
\hline 14 & $\begin{array}{l}\text { Breast pump } \\
\text { aja sampai } \\
\text { ada } 3 \text { hahaha } \\
\text { - p. } 418\end{array}$ & Insertion & $\begin{array}{c}\text { Intra- } \\
\text { sentential }\end{array}$ \\
\hline 15 & $\begin{array}{l}\text { Selaki dan } \\
\text { segalak apa } \\
\text { pun seorang } \\
\text { laki-laki, } \\
\text { begitu } \\
\text { cegukan } \\
\text { langsung } \\
\text { seperti a little } \\
\text { puppy yang } \\
\text { melas. } \\
\text { Kasiannya, } \\
\text { kamu Ben. - } \\
\text { p. } 425\end{array}$ & Insertion & $\begin{array}{c}\text { Intra- } \\
\text { sentential }\end{array}$ \\
\hline 16 & $\begin{array}{lr}\begin{array}{l}\text { He } \\
\text { clean }\end{array} & \text { smells } \\
\text { fresh. } & \text { and } \\
\text { gue } & \text { suka } \\
\text { wangi } & \text { sabun } \\
\text { itu, pernah } & \text { gue beliin } \\
\text { Creed } & \\
\text { Original } \\
\text { Vetiver yang } \\
\text { buat laki-laki } \\
\text { karena wangi } \\
\text { sabun juga. - } \\
\text { p. } 432\end{array}$ & alternation & $\begin{array}{c}\text { Inter- } \\
\text { sentential }\end{array}$ \\
\hline 17 & $\begin{array}{l}\text { Gue kebetulan } \\
\text { baru aja } \\
\text { selesai mandi } \\
\text { abis pulang } \\
\text { kantor juga. } \\
\text { So there we } \\
\text { were, di sofa } \\
\text { duduk } \\
\text { sebelahan } \\
\text { sambil } \\
\text { nonton. - p. } \\
433\end{array}$ & alternation & $\begin{array}{c}\text { Intra- } \\
\text { sentential }\end{array}$ \\
\hline 18 & $\begin{array}{l}\text { Tapi nanti kita } \\
\text { akan sampai } \\
\text { di suatu titik } \\
\text { bahwa risiko } \\
\text { itu terasa } \\
\text { worth it. }-\mathrm{p} \text {. } \\
442\end{array}$ & $\begin{array}{c}\text { Insertion } \\
\text { Congruent } \\
\text { lexicalization }\end{array}$ & $\begin{array}{c}\text { Intra- } \\
\text { sentential }\end{array}$ \\
\hline 19 & $\begin{array}{l}\text { Jadi } \\
\text { perempuan } \\
\text { kita nggak }\end{array}$ & Insertion & $\begin{array}{c}\text { Intra- } \\
\text { sentential }\end{array}$ \\
\hline
\end{tabular}

\begin{tabular}{|c|c|c|c|}
\hline & $\begin{array}{l}\text { boleh terlalu } \\
\text { clingy, harus } \\
\text { ditemenin } \\
\text { terus, harus } \\
\text { ditempelin } \\
\text { terus, harus } \\
\text { ditanya-tanya } \\
\text { terus. - p. } 443\end{array}$ & & \\
\hline 20 & $\begin{array}{l}\text { Bullshit itu } \\
\text { yang bilang } \\
\text { bisa mencintai } \\
\text { aja udah } \\
\text { bahagia. }-\mathrm{p} . \\
447\end{array}$ & $\begin{array}{c}\text { Insertion } \\
\text { Congruent } \\
\text { lexicalization }\end{array}$ & $\begin{array}{c}\text { Intra- } \\
\text { sentential }\end{array}$ \\
\hline 21 & $\begin{array}{l}\text { Kan inti } \\
\text { sebuah } \\
\text { hubungan } \\
\text { adalah trust. } \\
\text { Setia. Itu } \\
\text { harga mati. - } \\
\text { p. } 448\end{array}$ & Insertion & $\begin{array}{c}\text { Intra- } \\
\text { sentential }\end{array}$ \\
\hline 22 & $\begin{array}{l}\text { Pak Dokter ini } \\
\text { energinya } \\
\text { agak berlebih } \\
\text { ya setelah } \\
\text { Arsenal } \\
\text { menang. He's } \\
\text { now building } \\
\text { bookshelves } \\
\text { for Lil Ndut. } \\
\text { Bisa bacanya } \\
\text { aja kapan } \\
\text { hehehehe - p. } \\
450\end{array}$ & alternation & $\begin{array}{c}\text { Inter- } \\
\text { sentential }\end{array}$ \\
\hline 23 & $\begin{array}{l}\text { Kembali dari } \\
\text { RS, disuruh } \\
\text { pulang, false } \\
\text { alarm. Duh, } \\
\text { Lil Ndut bikin } \\
\text { Mommy deg- } \\
\text { degan dan } \\
\text { daddy kamu } \\
\text { stres aja. - p. } \\
454\end{array}$ & $\begin{array}{c}\text { Congruent } \\
\text { lexicalization }\end{array}$ & $\begin{array}{c}\text { Intra- } \\
\text { sentential }\end{array}$ \\
\hline 24 & $\begin{array}{l}\text { Kembali dari } \\
\text { RS, disuruh } \\
\text { pulang, false } \\
\text { alarm. Duh, } \\
\text { Lil Ndut bikin } \\
\text { Mommy deg- } \\
\text { degan dan } \\
\text { daddy kamu } \\
\text { stres aja. }-\mathrm{p} . \\
454\end{array}$ & Insertion & $\begin{array}{c}\text { Intra- } \\
\text { sentential }\end{array}$ \\
\hline 25 & $\begin{array}{l}\text { Besok kita } \\
\text { pulang ya, } \\
\text { Nak, you will } \\
\text { be home, } \\
\text { finally. - p. } \\
465\end{array}$ & alternation & $\begin{array}{c}\text { Intra- } \\
\text { sentential }\end{array}$ \\
\hline
\end{tabular}




\begin{tabular}{|c|c|c|c|}
\hline 26 & $\begin{array}{l}\text { Punya Arga } \\
\text { ini } \quad \text { bikin } \\
\text { makin cinta } \\
\text { sama } \\
\text { bapaknya. } \\
\text { He's a really } \\
\text { great dad } \\
\text { and husband. } \\
\text { Turun tangan } \\
\text { ikut ngurusin } \\
\text { Arga. } \\
\text { Bangun- } \\
\text { bangun } \\
\text { tengah malam } \\
\text { juga. - p.466 }\end{array}$ & alternation & $\begin{array}{c}\text { Inter- } \\
\text { sentential }\end{array}$ \\
\hline 27 & $\begin{array}{l}\text { Kasihan } \\
\text { anting-anting } \\
\text { yang di dalam } \\
\text { little box itu } \\
\text { jadi kalah } \\
\text { pamor sama } \\
\text { cap kaki Arga. } \\
\text { - p. } 468\end{array}$ & Insertion & $\begin{array}{c}\text { Intra- } \\
\text { sentential }\end{array}$ \\
\hline 28 & $\begin{array}{l}\text { Dulu gue } \\
\text { pernah bilang, } \\
\text { when you're } \\
\text { married, you } \\
\text { start to feel } \\
\text { for two } \\
\text { people. - p. } \\
473\end{array}$ & Alternation & $\begin{array}{c}\text { Intra- } \\
\text { sentential }\end{array}$ \\
\hline 29 & $\begin{array}{l}\text { Mungkin } \\
\text { karena this } \\
\text { little guy } \\
\text { represents } \\
\text { everything } \\
\text { that is the } \\
\text { best of me. - } \\
\text { p. } 473\end{array}$ & Alternation & $\begin{array}{c}\text { Intra- } \\
\text { sentential }\end{array}$ \\
\hline 30 & $\begin{array}{l}\text { Dia ada, dan } \\
\text { adanya dia itu } \\
\text { somehow jadi } \\
\text { semua yang } \\
\text { terbaik dalam } \\
\text { hidup gue - p. } \\
473\end{array}$ & Insertion & $\begin{array}{c}\text { Intra- } \\
\text { sentential }\end{array}$ \\
\hline
\end{tabular}

The writer analyzed based on the theories of Muysken (code mixing) and Romaine (code switching). The types of code mixing are insertion, alternation and congruent lexicalization. Then, the types of code switching are inter-sentential, intrasentential, tag switching.

\section{Code Mixing}

\section{a. Insertion}

1. Dia ada, dan adanya dia itu somehow jadi semua yang terbaik dalam hidup gue - p. 473.

The sentence (Alex) mix her language into English in the middle of her utterance. This case is classified as insertion, type of code mixing, because Alex inserts a word somehow in her base sentence. Alex inserted a word that is somehow, an adverb, to emphasize her feeling which means 'entah bagaimana' in Indonesian.

\section{Jadi perempuan kita nggak boleh terlalu clingy, harus ditemenin terus, harus ditempelin terus, harus ditanya-tanya terus. - p. 443}

The utterance above is mix the language into English and classified as insertion, type of code mixing, because Alex inserts a word clingy in the middle of her utterance which means 'lekat' in Indonesia. Alex prefers use the term in English to simplify her sentence.

3. Tiap main ke apartmen gue, juga langsung menjarah kulkas. Makanya selama pacaran grocery shopping gue tambah. That dude sure loves food. Untung nggak jadi gendut. - p. 300.

Alex mix her language into English in the middle of her utterance. This utterance above is classified as insertion, type of code mixing, because Alex inserts a word grocery shopping in her sentences. It is recognized as form of a phrase which means 'daftar belanjaan' in Indonesian.

4. Mau berburu new bed yang gede banget biar muat bobo bertiga sama Lil Ndut. - p. 338.

The word 'new bed' is mix her language into English in the middle of her utterance and classified as insertion, type of code mixing, because Alex inserts a word new bed in her base sentence. Alex inserted a phrase, a small unit of one language that is new bed, means 'kasur baru' in Indonesian.

5. Bullshit itu yang bilang bisa mencintai aja udah bahagia. - p. 447

The sentence (Alex) mix her language into English in front of her utterance. This utterance above is classified as insertion, type of code mixing, because Alex inserts a word bullshit in her sentences. It is recognized as noun which means 'omong kosong' in Indonesian.

\section{b. Alternation}

1. Mungkin karena this little guy represents everything that is the best of me. - p. 473

Alex mixes her language into English. This case is identified as alternation, type of code mixing, 
because this little guy represents everything that is the best of me is a form of clause that occurs in a base sentence. Alex mixes her language because she gets used to speak English and she feels more comfortable to express her feeling using English. It means 'lelaki kecil ini mewakili semua yang terbaik dari diriku' in Indonesian.

\section{Dulu gue pernah bilang, when you're married, you start to feel for two people. - p. 473}

This utterance is mix the language into English and classified as alternation because when you're married, you start to feel for two people is a form of clause that occur in a base sentence which means 'ketika Anda menikah, Anda mulai merasakan dua orang' in Indonesian. Alex mixes her language when she emphasize her sentence. It is also type of code mixing.

3. Men are not mind readers. Semuanya harus dinyatakan verbal, hinting is usually useless. - p. 383.

The utterance can be categorized as alternation because the types of code mixing above found in a complete sentence. There are 2 alternation found, such as Men are not mind readers and hinting is usually useless which means 'Laki-laki bukan pembaca pikiran' and 'isyarat itu biasanya tidak berguna' in Indonesian. Those are recognized as form of a clause.

4. Lil Ndut, nanti tiap malam Mommy yang ceritacerita nggak apa-apa ya, Nak. Time for you to listen to other stories. - p. 387.

The utterance above, it can be seen the speaker (Alex) mix the language from Indonesia into English which means categorized as alternation. Time for you to listen to other stories which means in Indonesia 'saatnya kamu mendengarkan cerita lainnya'. It is also type of code mixing that recognized as form of a clause.

5. Besok kita pulang ya, Nak, you will be home, finally. - p. 465

This utterance belongs to alternation, type of code mixing, since Alex mixes her language into English. You will be home, finally is a form of clause that occurs in a base sentence because she gets used to speak English and she feels more comfortable to express her feeling using English. It means 'kamu akan pulang juga akhirnya' in Indonesian.

\section{c. Congruent Lexicalization}

1. Kembali dari RS, disuruh pulang, false alarm. Duh, Lil Ndut bikin Mommy deg-degan dan daddy kamu stres aja. - p. 454

The utterance above is classified as congruent lexicalization because congruent lexicalization is code mixing that occurs at the phonological level, as when Indonesian people says an English word, but modify it to Indonesian phonological structure. Indonesian call "stres" with the same phonological "stress" in English.

2. Waktu gue lunch dengan ibu mertua minggu lalu, salah satu tante si Beno itu nelepon ibu, dan ibu cerita tentang kehamilan gue. - p. 290.

The utterance above is classified as types of code mixing - congruent lexicalization because the word of 'lunch' used to describe the situation of the person and many person already know the meaning of 'lunch' then in Indonesian is 'makan siang'.

3. Tapi nanti kita akan sampai di suatu titik bahwa risiko itu terasa worth it. - p. 442

The utterance belongs to classified as congruent lexicalization the types of code mixing because the word of 'worth it' used to describe the value of something and many person already familiar the meaning of 'worth it' then in Indonesian is 'sepadan'.

4. Bullshit itu yang bilang bisa mencintai aja udah bahagia. - p. 447

The utterance belongs to classified as congruent lexicalization the types of code mixing because the word of 'bullshit' used to describe the value of something and many person already familiar the meaning of 'bullshit' then in Indonesian is 'omong kosong'.

\section{Code Switching}

\section{a. Inter-sentential}

1. In the backseat with si anti public display of affection yang ikut nganter ke bandara. Karena ada sopir, si anti public display of affection tidur di sebelah gue sambil megang tangan aja. Cute. - p. 255.

From the utterance above, Alex (the character in Twivortiare 2 novel) deliberately switch from English to Indonesian when she describes a moment she went to the airport. In the backseat with, anti public display of affection, cute are classified into intersentential code-switching because the switching occurs within the sentence. In this sentence, Alex also makes a label for his husband as anti 
public display of affection. Anti public display of affection means person that does not want to show their making out activity in a public places (bermesraan di depan umum). Alex prefers uses the label in English than in Indonesian because it is difficult to find a right term for that condition.

2. Waktu gue lunch dengan ibu mertua minggu lalu, salah satu tante si Beno itu nelepon ibu, dan ibu cerita tentang kehamilan gue. - p. 290.

Alex inserted a phrase "lunch" in her utterance, and it is classified into intrasentential switching because the word "lunch" found within the sentece in a base language, which is Indonesian.

3. Mau berburu new bed yang gede banget biar muat bobo bertiga sama Lil Ndut. - p. 338.

This utterance shows that Alex switch her language from Indonesian to English. Since the switch has occurred within sentence, it is classified into intra-sentential switching. Alex prefers use the word "new bed" than "tempat tidur baru" because Alex is a simple women and "new bed" is simpler than "tempat tidur baru". The other reason why Alex often uses English because she often has meeting with a foreign so English has already became her second language.

4. Kembali dari RS, disuruh pulang, false alarm. Duh, Lil Ndut bikin Mommy degdegan dan daddy kamu stres aja. - p. 454

Alex switches her language from Indonesian to English. Alex prefer use English in her sentence because she talks about particular topic and the word that Alex used is common term in that topic. "False Alarm" means kontraksi palsu. This case is classified in intra-sentential cod-switching because it happens within a sentence.

5. Kasihan anting-anting yang di dalam little box itu jadi kalah pamor sama cap kaki Arga. - p. 468

This utterance is classified into intrasentential code switching because the switch occurs within the sentence. Alex switches the language from Indonesian to English because she gets used to use English in her daily life to support her job.
1. Tiap main ke apartmen gue, juga langsung menjarah kulkas. Makanya selama pacaran grocery shopping gue tambah. That dude sure loves food. Untung nggak jadi gendut. p. 300 .

The utterance above classified into intersentential code switching because Alex switches her language from Indonesia to English occurs in a complete sentence and appear after the base language sentence.

2. Punya Arga ini bikin makin cinta sama bapaknya. He's a really great dad and husband. Turun tangan ikut ngurusin Arga. Bangun-bangun tengah malam juga. - p. 466

Alex switches her language from Indonesian to English. This switch is classified as inter-sentential code because this case occurs at sentence boundaries. Alex switches her language to express her feeling about her husband.

3. Pak Dokter ini energinya agak berlebih ya setelah Arsenal menang. He's now building bookshelves for Lil Ndut. Bisa bacanya aja kapan hehehehe - p. 450

This sentence is classified as intersentential code since it happens at sentence boundary. Alex switches her language from Indonesian to English because she want to describe her feeling about her husband attitude.

4. Lil Ndut, nanti tiap malam Mommy yang cerita-cerita nggak apa-apa ya, Nak. Time for you to listen to other stories. - p. 387.

The utterance above is inter-sentential switching because the changing of language occurs in a completed sentence. Beno switch his language from Indonesian to English because his wife, Alex, usually talk in English. It make Beno get used to speak English. Our partner in communication sometime influence our way in using language.

5. Lebih tepatnya bukan ke orangnya. But bored of the way we interact, sometimes. Hidup gue sama Beno kan kayak clock-work, no surprise. - p. 409.

Alex switches the language from Indonesian to English in complete sentences that is why this case is classified into inter-sentential switching. Alex feels more comfortable using English to describe her feeling.

\section{b. Intra-sentential}




\section{Conclusion}

Focusing on classification types of code mixing and code switching based on twivortiare 2 novel, the writer found several uterrance related code mixing and code switching. It reveals with code mixing using insertation 16, alternation 13, congruent lexicalization 4. Thus code switching using Intrasentential 23, Inter-sentential 7. In twivortiare 2 novel, most of utterance using code mixing insertation and code switching - intra-setential which relevant the situation according to the novel.

\section{REFERENCES:}

Appel, R., \& Muysken, P. (2006). Language Contact and Bilingualism. Amsterdam University Press.

Bullock, B. ., \& Toribio, A. J. . (2009). The Cambridge Handbook of Linguistic Code Switching. Cambridge University Press.

Chaer, A., \& Agustina, L. (2010). Sociolinguistik:Perkenalan Awal. Rineka CIpta.

Holmes, J., \& Wilson, N. (2017). An Introduction to Sociolinguistics. Routledge.

Husna, I. (2010). Code Mixing and Code Switching in Ketika Cinta Bertasbih I Novel. University of Brawijaya.

Muysken, P. (2000). A Typology of Codemixing. Cambridge University Press.

Nassaji, H. (2015). Qualitative and Descriptive Research: Data Type Versus Data Analysis. Language Teaching Research, 19(2), 129-132.

Ika Natassa. (2014). Twivortiare 2. Gramedia Pustaka Utama.

Poplack, S. (1980). Sometimes I'll start a sentence in Spanish y termino es espanol: toward a typology of code-switching. Linguistics, 18, 581-618.

Romaine, S. (1995). Bilingualism Second Edition. Blackwell.

Suwito. (1985). Pengantar Awal Sociolinguistik Teori dan Problema. Surakarta Henary Offset.

Wardhaugh, R. (1998). An Introduction to Sociolinguistics : Third Edition. Blackwell. 